\title{
Knowledge, Attitude, and Behavior of Parents toward School Reopening Amidst Coronavirus Disease 2019 Pandemic in Indonesia
}

\author{
Andry Juliansen ${ }^{1}$, Gilbert Sterling Octavius ${ }^{2 *} \mathbb{D}$, Alexa Ovilia $\operatorname{Tan}^{2} \mathbb{D}$, Chelsea Serena Br. Pardede ${ }^{2}$ iD, Cindy Clarissa Thandy ${ }^{2}$, \\ Clauvinna Adhityana Lie Fisca ${ }^{2}$, Jeremiah Hilkiah Wijaya ${ }^{2}$ \\ ${ }^{1}$ Department of Medicine, Faculty of Medicine, University of Pelita Harapan, Tangerang, Banten, Indonesia; ${ }^{2}$ Department of \\ Medicine, Faculty of Medicine, University of Pelita Harapan, Tangerang, Banten, Indonesia
}

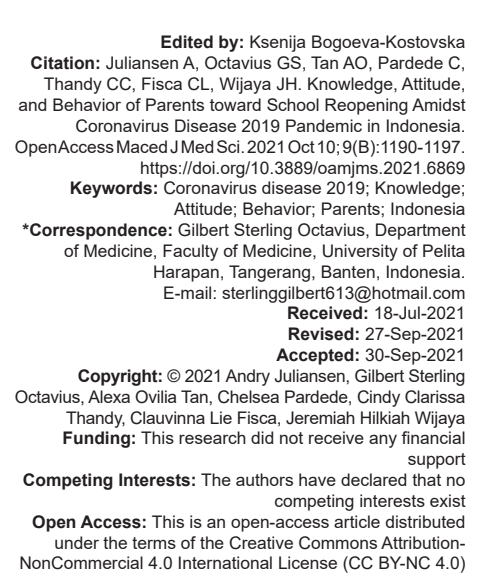

\begin{abstract}
AIM: Recently, the subject of reopening schools has raised several concerns, especially on the possibility of new coronavirus disease 2019 (COVID-19) cluster cases. Parent's role is essential in this matter. Therefore, this study aims to understand the parents' knowledge, attitude, and behavior toward COVID-19 in Indonesia.

METHODS: A cross-sectional study was conducted on 206 Indonesian parents. A 55-items questionnaire was used to assess the knowledge, attitude, and behavior of subjects. In this study, median split tests, Kruskal-Wallis, Cronbach's $\alpha$, and Pearson correlation test were used.

RESULTS: Subjects were found to have high levels of knowledge, especially in the knowledge of COVID-19 as a contagious viral disease $(98.5 \%)$, and the necessity for children to maintain personal hygiene to prevent COVID- 19 (98.5\%). Subjects' attitudes were highest at understanding how to prevent COVID-19 (95.1\%) and teaching children how to avoid COVID-19 (98.1\%). Subjects' attitude was lowest at hearing the news of the death of COVID-19 scares them (72.8\%), and on how their children are getting bored at home because of COVID-19 (69.9\%) Subjects' are shown to have high levels of behavior in every question. This study found a significant correlation between socioeconomic status and subjects' knowledge $(p=0.007)$

CONCLUSION: This study revealed a lack of understanding of prevention strategies among low-income households. Hence, there is a need for targeted messaging and health education in low-income settings that consider the challenges they may face when attempting their children to practice COVID-19 prevention procedures if schools reopen.
\end{abstract}

\section{Introduction}

More than a year has passed since the initial announcement of a positive case of severe acute respiratory syndrome coronavirus 2 (SARS-CoV-2) in Indonesia. Up to June 21, 2021, the number has soared up to more than 1.9 million people who tested positive for the disease, 1.7 million recovered, and more than 54 thousand fatalities [1]. The health authorities' initiatives in taming this highly transmissible virus are seemingly effective, but there has not been any sign of normalcy [2], [3].

Of note, more than one-third of the Indonesian population are children (79.55 million or $30.1 \%$ ) [4]. Coronavirus disease 2019 (COVID-19) is challenging to diagnose in children due to the lack of specificity of its symptoms (fever, exhaustion, and dry cough), making it difficult to distinguish it from other pediatric viral diseases. The first COVID-19 pediatric case in Indonesia is not well documented. However, on July 20, 2020, a total of 2712 positive SARS-CoV-2 infections was known to occur in children. It is the highest number in Southeast Asia [5]. Infection with a respiratory virus in school-aged children is an epidemiologic concern as new clusters might arise from school when it is allowed to reopen [6]. It is unknown whether school closures are beneficial during coronavirus epidemics such as SARS, Middle East respiratory syndrome, or SARS-CoV-2, which appears to have different transmission dynamics [7]. Since most teachers have been vaccinated, the Indonesian government plans to reopen the schools [8], but the safety and efficacy of the COVID-19 vaccine for children under 12 years old, on the other hand, have not been reported [9], [10]. The subject of restarting school, of course, raises several issues [11].

According to Ikatan Dokter Anak Indonesia (IDAI), also known as the Indonesian Pediatric Society (IPS), children should stay at home throughout the COVID-19 pandemic. They also do not recommend reopening school until the local infectivity rate is $<5 \%$. Even if they consider face-to-face classes, IDAl advises them to conduct a hybrid learning method [12]. 
Parent's role is undoubtedly essential as they are their children's educator in implementing the proper health protocols. They need to make a crucial decision whether to allow their children to attend in-person classes as parents' consent are needed to allow their children to attend face-to-face classes [13]. Therefore, the parents' knowledge, attitude, and practices regarding the prevention of COVID-19 for their children are vital in protecting children from the risk of COVID-19 transmission. The public's awareness and perceptions about COVID-19 are likely to affect compliance as well. Evidence suggests that public awareness is critical in combating pandemics [14], [15], [16]. Deeper insights into current parents' perceptions and behaviors can be obtained by analyzing general understanding and information about the coronavirus, thus identifying characteristics that affect the parents in adopting safe practices and sensitive demeanor for their children [17]. It is also necessary to assess parents' awareness to improve existing prevention programs. Therefore, this study aims to understand the parents' knowledge, attitude, and behavior toward COVID-19 in Indonesia, especially regarding the decision to let their children attend schools again.

\section{Materials and Methods}

\section{Study sampling}

This study was a cross-sectional study utilizing purposive sampling and after adjusting for alpha of 0.05 and $80 \%$ power, the minimum sample size required is 176 respondents [18]. The data were collected by means of Google form from December 14, 2020, to January 3,2021 . The questionnaire link was sent through email and WhatsApp to the potential respondents. We included explanations about the research, and conscious participation was strongly encouraged in the online questionnaire. All parents who receive this link and have internet access can participate in this study. The inclusion criteria are parents of pediatric polyclinic patients at RSUS Karawaci, parents who have children within the age range of 6-18 years old who are participating in online school, and parents who have activities outside of the house during the pandemic. The online questionnaire took 8-10 $\mathrm{min}$ to answer. The exclusion criteria were patients who did not consent to the study as well as parents who are not in the right medical conditions to fill-up the form, such as being bed-ridden due to severe illnesses.

\section{Questionnaire description}

The questionnaire used in this study consisted of 55 questions divided into five sections. It was adopted from a study by Nourmoradi et al. [19].
Questionnaires are reviewed by a panel of experts, where unnecessary parts or items that were deemed unsuitable were eliminated. Then, the questionnaire was forward translated to the Indonesian language by a certified translator. The expert panel then reviewed the questionnaire once again. After some tweaks to ensure smooth readability, the questionnaire was then backtranslated to the English language. The penultimate questionnaire was then pilot tested on five parents, and these samples were not included in the analysis. Finally, the final questionnaire was then administered to all participants.

The first part of the questionnaire evaluated the subjects' demographic information such as age, gender, level of education, job status, family economic status, place of residence, and number of children currently still enrolled in school.

The second part of the questionnaire assesses where the subjects get their information from. This part consisted of five questions ranging from where they get their information from, if they have been tested for COVID-19 and which tests the parents took, and if they have gotten COVID-19.

The third part of the questionnaire was given to determine the knowledge of the subjects on COVID-19 with 12 items. The answers were scored as follows: If the participant answered Yes, the participant would be given a score of two; if the participant answered I do not know, they would be given a score of one, and if they answered no, they would be given a score of zero. The total knowledge scores range from a minimum of zero to a maximum score of 24 . The higher the scores indicate a higher level of knowledge of the subject on COVID-19.

The fourth section was given to determine the subject's attitude on COVID-19 using eight items. The answers were scored by a five-point Likert scale, starting from one if they disagree entirely and ending in five if they completely agree. The scores ranged from a minimum of eight to a maximum score of 40 . Higher scores from this section indicate a more appropriate attitude.

The last section of the questionnaire was given to determine the behavior of subjects' during the pandemic. This section consisted of ten items, which were scored by a five-point Likert scale with the same scoring as the previous section. The scores ranged from a minimum score of 10 and a maximum score of 50 , with a higher score on this section indicates a more appropriate behavior. The full set of the questionnaire can be seen in Appendix A. Median split tests were used to assess which score was high and low based on the total score of knowledge, attitude, and behavior [20].

\section{Data analysis}

IBM SPSS Statistics 26 Statistical Package (IBM Corp., Armonk, NY, USA) was used to analyze 
the research data. Normality in data was assessed using Kolmogorov-Smirnov test. If the data distribution was not normal, median and range would represent the data, while mean and standard deviation would be used if data distribution was normal. Non-parametric and continuous data would be analyzed with KruskalWallis. In this study, $p<0.05$ was considered statistically significant. The internal reliability of the questionnaire was assessed using Cronbach's $\alpha$, while validity was assessed using the Pearson correlation test.

\section{Results}

\section{Demographic variables}

The Cronbach's $\alpha$ value for knowledge, attitude, and behavior is $0.691,0.714$, and 0.848 , respectively (Table 1). Item knowledge 9 (K9) has to be dropped as its value was below 0.6 and dragged the whole Cronbach's $\alpha$ value down. Hence, the questionnaire is moderate to strongly reliable for assessing knowledge, attitude, and behavior in this population [19]. The Pearson correlation value product is more than the $r$ table for each item; therefore, the questionnaire is valid in assessing this population's knowledge, attitude, and behavior.

Table 1: Internal validity and reliability of the questionnaire

\begin{tabular}{llll}
\hline Variable & Total knowledge score & Total attitude score & Total behavior score \\
\hline
\end{tabular}

There are 206 parents in this study, with three of the respondents being excluded for incomplete data (Figure 1). A majority of the respondents are mothers $(73.8 \%)$, medical workers (43.7\%), and have bachelor's degrees $(30.1 \%)$ with a median of 38 years old (19-62 years old) (Table 2). The participant's knowledge is significantly correlated with socioeconomic status. In this study, we find that occupation has no significant correlation with knowledge $(p=0.389)$, behavior $(p=0.223)$, and attitude $(p=0.201)$ of parents. In addition,

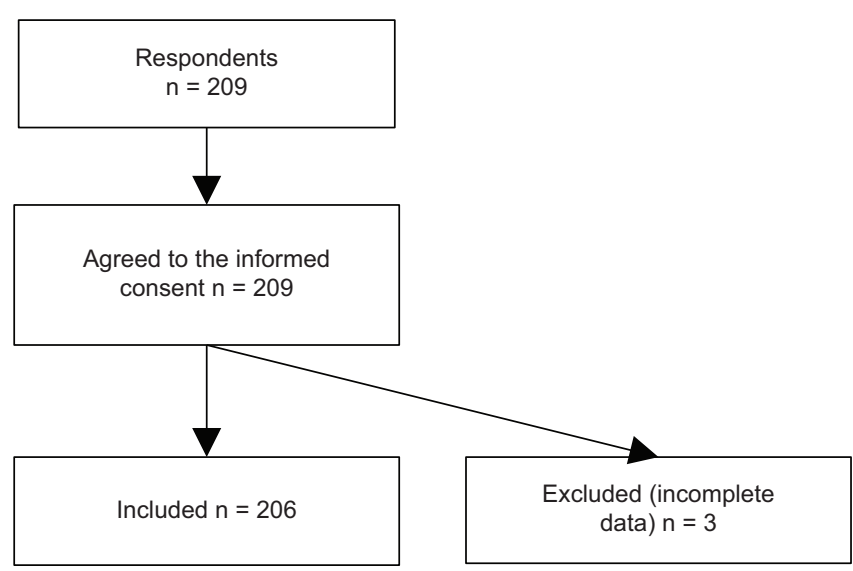

Figure 1: Samples Inclusion-Exclusion Flow Diagram we found no significant correlation between educational background with knowledge $(p=0.114)$, attitude ( $p$ $=0.831)$, and behavior $(p=0.487)$. The correlation between socioeconomic status and attitude scoring was also statistically insignificant $(p=0.589)$, and the same goes for the correlation between socioeconomic status with behavior scoring $(p=0.621)$. However, it correlates significantly with knowledge scoring ( $p=0.007)$.

Based on the results of the questionnaire (Table 3), subjects have high levels of knowledge to the majority of the questions (Figure 2), especially in the knowledge of COVID-19 as a contagious disease caused by a virus (98.5\%), and the necessity for children to maintain personal hygiene to prevent COVID-19 (98.5\%). While, subjects' knowledge of how healthy children (without comorbidities) only need to use a three-layer cloth mask $(65 \%)$ and the recommendation to reopen school by IDAI $(65.5 \%)$ are shown to be at lower levels. Subjects' attitudes were highest at understanding how to prevent COVID$19(95.1 \%)$ and teaching children how to avoid COVID$19(98.1 \%)$. However, the subjects' attitude was lowest at hearing the news of the death of COVID-19 scares them $(72.8 \%)$, disagreeing the reopening of school $(74.2 \%)$, and on how their children are getting bored at home because of COVID- 19 (69.9\%). For their behavior, subjects are shown to have high levels of behavior in every question, with the highest percentage on parents' agreement to teach their children to wash their hands properly $(99.5 \%)$, the proper etiquette of coughing and sneezing (99.5\%), and not to touch the eyes, nose, and mouth area while in school (99.5\%).

\section{Discussion}

This study shows satisfactory results in parents' knowledge, attitude, and behavior toward COVID-19. A similar study by Abuhammad (2020) showed that parents understood clinical signs, transmission mode, and disease protection measures. Hence, sufficient knowledge, a positive attitude, and good hygiene practice by parents are the domains required to be translated and applied toward children's COVID-19 prevention and control [21].

The findings showed that participants had adequate knowledge of COVID-19. Parents' knowledge of how COVID-19 is a contagious disease caused by a virus and can infect children shows a satisfactory result. A high percentage of parents also understand how children presenting no symptoms may also be infected with COVID-19. Results regarding understanding the signs of COVID-19 and the primary transmission route being respiratory droplets and protection measures are adequate. This is consistent with the finding of Abuhammad (2020) and Roy et al. (2020) [21], [22]. 
Table 2: Comparison of mean scores and standard deviation of knowledge, attitude, and behavior of the participants based on socio-demographic characteristics

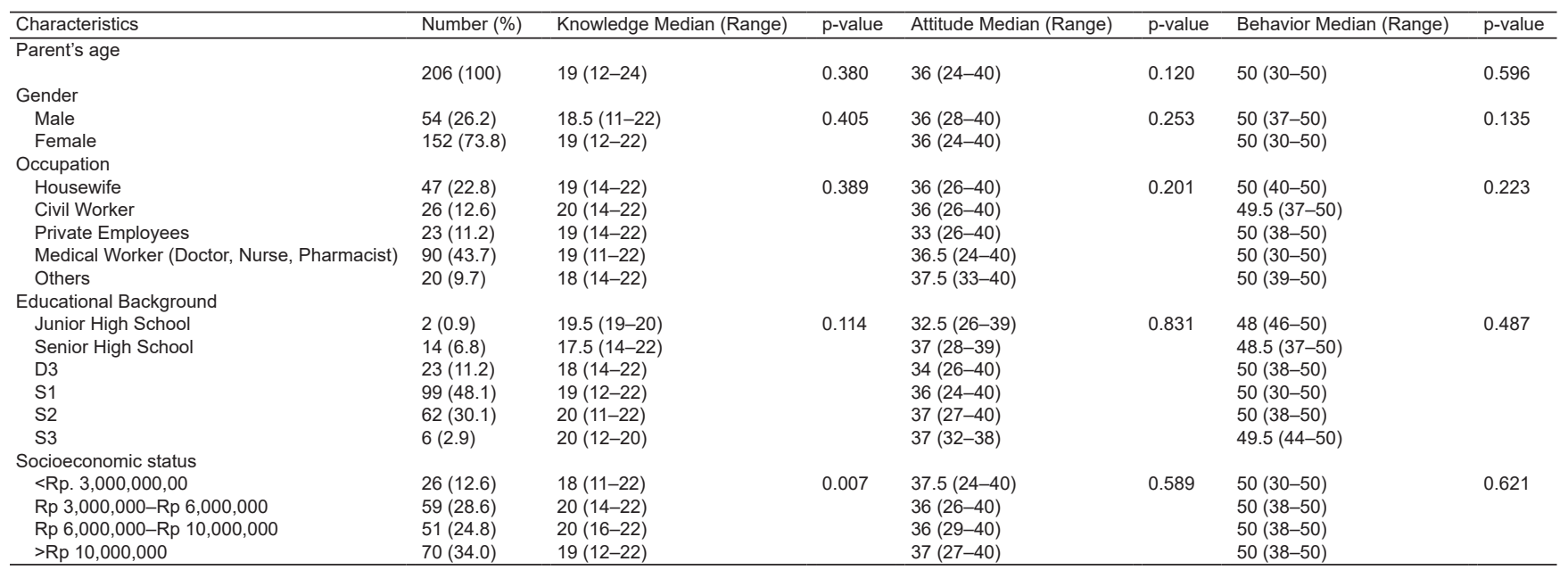

However, the false fact regarding children under 5 years not recommended to use masks is agreed by a meaningful percentage of respondents. The same goes for the IPS statement allowing schools to reopen, falsely agreed, and unknown by some respondents [12]. These unsatisfactory results may be due to the socioeconomic status of respondents. Here, we found that socioeconomic plays a role in determining the difference between participants' knowledge. Individuals with a lower income have a more insufficient understanding of the prevention, clinical signs, and information related to COVID-19. This result correlates with Zhong et al. (2020), which suggest that Chinese residents of a relatively high socioeconomic level had a good level of knowledge toward COVID-19 [23]. The result shows no significant correlation between parents' age, gender, occupations, and educational background to the knowledge about COVID-19.

This study found that the majority of the respondents have a good attitude toward COVID-19. Results showed that $95.1 \%$ understand how to prevent the infection of COVID-19. This result is consistent

Table 3: Relative frequency (\%) of participants' answers to questionnaire items ( $n=206$ )

\begin{tabular}{|c|c|c|c|c|c|}
\hline Items no & Answers (\%) & & & & \\
\hline Knowledge & Yes & & No & & I do not know \\
\hline COVID-19 is a contagious disease caused by a virus & $203(98.5)$ & & $0(0)$ & & $3(1.5)$ \\
\hline COVID-19 cannot infect children & $10(4.8)$ & & $195(94.7)$ & & $1(0.5)$ \\
\hline Ikatan Dokter Anak Indonesia (IDAI) has allowed school to reopen & $31(15)$ & & $135(65.6)$ & & $40(19.4)$ \\
\hline $\begin{array}{l}\text { According to the World Health Organization (WHO), children under } 5 \text { years } \\
\text { old are not recommended to use masks }\end{array}$ & $44(21.4)$ & & $143(69.4)$ & & $19(9.2)$ \\
\hline Children who do not show any symptoms are unlikely to catch COVID-19 & $4(1.9)$ & & $198(96.2)$ & & $4(1.9)$ \\
\hline One of the symptoms of COVID-19 in children is fever & $196(95.1)$ & & $2(1)$ & & $8(3.9)$ \\
\hline COVID-19 infection is not life-threatening or harmless to children & $14(6.8)$ & & $189(91.7)$ & & $3(1.5)$ \\
\hline $\begin{array}{l}\text { Person to person transmission of COVID-19 can occur through } \\
\text { droplets (while talking, sneezing, coughing, singing, etc.) }\end{array}$ & $201(97.6)$ & & $2(1)$ & & $3(1.4)$ \\
\hline $\begin{array}{l}\text { Children over the age of } 5 \text { who are healthy (without symptoms) do not need } \\
\text { to wear a mask }\end{array}$ & $10(4.8)$ & & $194(94.2)$ & & $2(1)$ \\
\hline $\begin{array}{l}\text { Children are encouraged to maintain personal hygiene (washing hands, } \\
\text { showering after traveling, etc.) to prevent COVID-19 }\end{array}$ & $203(98.5)$ & & $2(1)$ & & $1(0.5)$ \\
\hline $\begin{array}{l}\text { Healthy children (without comorbidities) only need to use a three-layer cloth } \\
\text { mask }\end{array}$ & $134(65)$ & & $66(32)$ & & $6(3)$ \\
\hline Attitude & Completely agree & Agree & Neutral & Disagree & Completely disagree \\
\hline I understand how COVID-19 is transmitted & $146(70.9)$ & $49(23.8)$ & $10(4.8)$ & $0(0)$ & $1(0.5)$ \\
\hline I understand how to prevent COVID-19 & $155(75.2)$ & $41(19.9)$ & $9(4.4)$ & $0(0)$ & $1(0.5)$ \\
\hline Hearing the news of the death of COVID-19 scares me & $104(50.5)$ & $46(22.3)$ & $39(19)$ & $13(6.3)$ & $4(1.9)$ \\
\hline $\begin{array}{l}\text { I am afraid that my child will be infected with COVID- } 19 \text { when he/she goes } \\
\text { back to school }\end{array}$ & $146(70.9)$ & $34(16.5)$ & $19(9.2)$ & $6(2.9)$ & $1(0.5)$ \\
\hline My child (ren) will be safer studying from home rather than at school & $141(68.5)$ & $32(15.5)$ & $25(12.1)$ & $7(3.4)$ & $1(0.5)$ \\
\hline I do not agree for schools to reopen & $114(55.3)$ & 39 (18.9) & 39 (18.9) & $8(3.9)$ & $6(3)$ \\
\hline I will teach my children on how to prevent COVID-19 & $178(86.4)$ & $24(11.7)$ & $4(1.9)$ & $0(0)$ & $0(0)$ \\
\hline My child (ren) are getting bored at home because of COVID-19 & $93(45.1)$ & $51(24.8)$ & $42(20.4)$ & $11(5.3)$ & $9(4.4)$ \\
\hline Behavior & Completely agree & Agree & Neutral & Disagree & Completely disagree \\
\hline I will prepare food and utensils from home & $168(81.6)$ & $24(11.6)$ & $8(3.9)$ & $2(1)$ & $4(1.9)$ \\
\hline I will prepare a mask for my child before going to school & $190(92.2)$ & $12(5.8)$ & $2(1)$ & $1(0.5)$ & $1(0.5)$ \\
\hline I will prepare a face shield for my child before going to school & $176(85.4)$ & $23(11.2)$ & $4(1.9)$ & $2(1)$ & $1(0.5)$ \\
\hline I will clean or disinfect my child's school supplies everyday & $163(79.1)$ & $32(15.5)$ & $10(4.9)$ & $1(0.5)$ & $0(0)$ \\
\hline I will teach my child (ren) to wash his/her hands properly & $188(91.3)$ & $17(8.2)$ & $1(0.5)$ & $0(0)$ & $0(0)$ \\
\hline $\begin{array}{l}\text { I will teach my child how to maintain a distance of minimum } 1 \text { meter from } \\
\text { his/her friends }\end{array}$ & $182(88.4)$ & $19(9.2)$ & $5(2.4)$ & $0(0)$ & $0(0)$ \\
\hline I will teach my child the proper etiquette of coughing and sneezing & $184(89.3)$ & $21(10.2)$ & $1(0.5)$ & $0(0)$ & $0(0)$ \\
\hline $\begin{array}{l}\text { I will teach my child not to touch the eye, nose, and mouth area while in } \\
\text { school }\end{array}$ & $187(90.8)$ & $18(8.7)$ & $1(0.5)$ & $0(0)$ & $0(0)$ \\
\hline I will not take my child out if it is not needed & $168(81.5)$ & $33(16)$ & $3(1.5)$ & $2(1)$ & $0(0)$ \\
\hline $\begin{array}{l}\text { I will rest my child at home if there are signs and symptoms of } \\
\text { COVID-19 (fever, cough, runny nose, diarrhea, etc.) }\end{array}$ & $185(89.8)$ & $16(7.7)$ & $2(1)$ & $1(0.5)$ & $2(1)$ \\
\hline
\end{tabular}

${ }^{*}$ For knowledge items no 2, 3, 4, 5, 7, 9, and 10, the correct answer is no, COVID-19: Coronavirus disease 2019. 


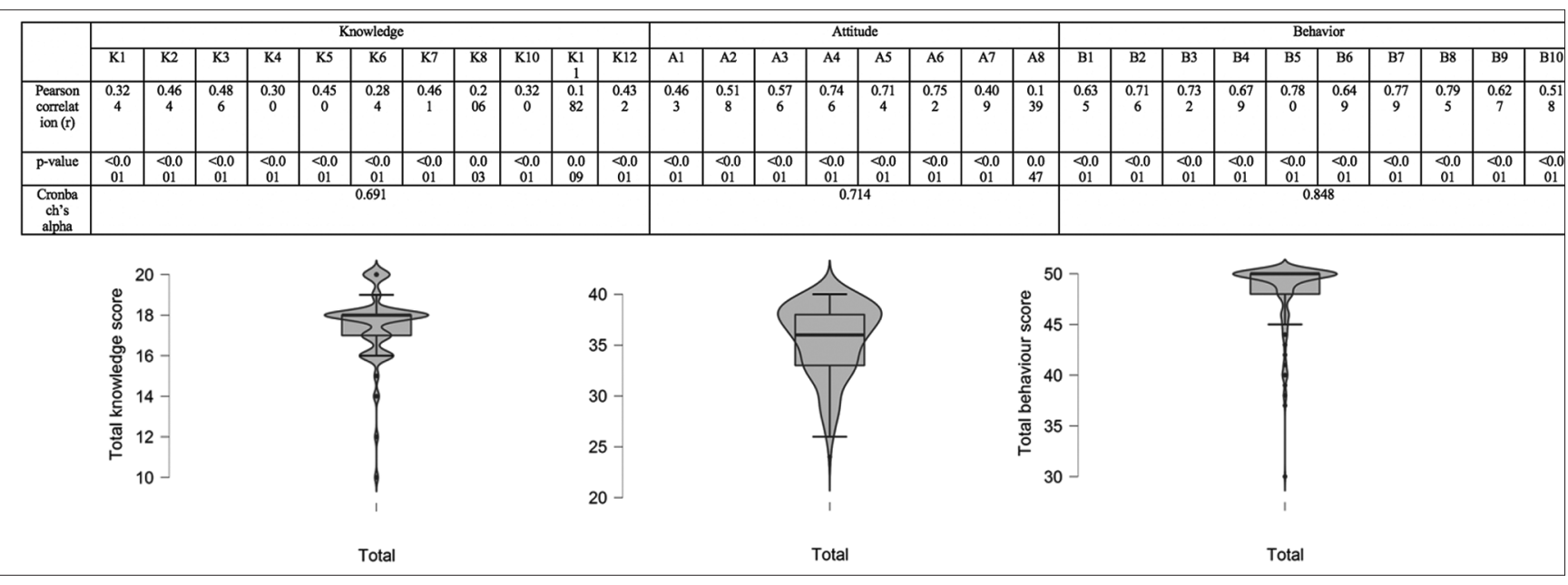

Figure 2: Violin graph of total scores of knowledge (left), attitude (middle), and behavior (right)

with the findings in a previous study conducted in Africa, which found that $81 \%$ of respondents valued the importance of personal hygiene, self-isolation, masks, and social distancing, which are the means of COVID-19 infection prevention [24]. This result is also consistent with a study in South Korea which found that most respondents believed in the efficacy of preventive measures such as personal hygiene and social distancing [16]. Regarding the attitudes of the agreement to the governmental measures of lockdown and closing the schools, $75 \%$ of parents complied with the government on their measures. This result is quite different from a previous study showing more than $95 \%$ of parents agreed.

Analysis between demographic factors and the attitude of respondents toward COVID-19 showed that demographic factors such as parent's age, gender, occupation, educational background, and income status did not significantly affect the attitude toward COVID-19. This result is similar to a study by Lee et al., which found that age, education level, and income level did not significantly affect the respondent's attitude. However, they found that respondent's gender was significantly associated with their attitude [16]. However, a study in China found that factors such as gender, age, education, and occupation are significantly associated with respondent's attitudes toward COVID- 19 [23]. Discrepancies between these studies results may be caused by differences in the assessed points of attitude. In this study, we evaluated respondent's attitude toward their understanding of how COVID-19 transmitted or ways to prevent COVID-19 infection, and their understanding of how COVID-19 impacted their children, while the study by Zhong et al. evaluated respondent's attitude on their confidence in winning or battling COVID-19 pandemic and if they can succeed in controlling COVID-19 [23].

A study in Bangladesh also found that sociodemographicfactorssuchashighfamilyincomecorrelated with a more positive attitude towards COVID- 19 [25]. Multiple studies conducted in various countries have shown similar results [26], [27], [28], [29]. This is partly due to the low education opportunities they have in Indonesia. Hence, they might have misinformation or poor socialization regarding the COVID-19 facts [30]. In terms of attitude, it is significantly affected by parent's age, which shows that older parents tend to perform a better attitude in preventing COVID-19. The high awareness level might be the underlying reason as they recognized the outcomes COVID-19 carries and their age is way too vulnerable [31]. This awareness is observed ever since the beginning of the pandemic. Thirdly, one's behavior differed most significantly by sex. This is supported by several findings, such as women-led countries, such as Germany and New Zealand, have generally fared better in the face of the pandemic. In contrast, some of the worst-performing countries, such as the United States and Brazil, are led by men who project strong masculinity attitudes and dismiss the need for precautionary measures such as wearing masks [26], [32], [33].

The findings of this study have ramifications for the development of low-income response initiatives. Social distancing and avoiding large crowds are examples that aim to control transmission by lowering contact rates in the general population [34]. Such measures will continue to be critical in the global response to COVID-19 until a vaccine is available. However, they are necessary for this population where any pharmaceutical intervention may be difficult to access by reasons of high cost or low distribution [26]. While these findings reveal a lack of understanding of prevention strategies among low-income households. There is also growing acknowledgment that people living in densely populated urban slums and other lowincome communities are unlikely to have the spatial and economic capacity to engage in social distancing and self-isolation. Mitigation strategies will need to account for populations experiencing poverty who may not have fixed incomes, so cash transfers to enable households to "stay-at-home" have been suggested [35]. However, it is encouraging to see that those who knew more about 
the virus's potential transmission routes also reported taking more antiviral precautions [36]. While this link between knowledge and practice emphasizes the importance of widespread public health messaging and information campaigns as the situation evolves, there is a need for targeted messaging and health education in low-income settings that consider the challenges that these populations may face when attempting to practice COVID-19 preventions.

This research is far from perfect and has several limitations. First, the study was conducted online, and because of that, parents who do not have access to the internet and smartphones could not give their participate and may result in selection bias. Second, the subject in this study mostly had a university degree. The National's Statistic Data in 2020 stated that society is dominated by primary school graduates $(38.89 \%)$, followed by high school graduates $(18.27 \%)$, while people with a university degree only reach $9.69 \%$ [37]. Therefore, it is possible that the level of knowledge and attitude, and behavior in this study were higher than the actual general population in Indonesia. Given that the pace of the information and knowledge of COVID-19 is everchanging, questions given to respondents may not apply now. Finally, with current spikes in new cases of COVID-19, as well as rapidly changing government policies about reopening schools, parents might be influenced by other internal and external factors not studied in this research that might affect their knowledge attitude behavior toward letting their children attend schools again.

\section{Conclusion}

This research aims to determine parents' knowledge, attitude, and behavior toward their children in Indonesia towards COVID-19. The findings in this study showed that most participants were aware and had a high level of knowledge to answer most of the questions that assess parents' knowledge, attitude, and behavior in Indonesia towards COVID-19. Most participants already have good knowledge, attitude, and behavior of the etiology of COVID-19, COVID-19 prevention in themselves and their children, especially hand washing, proper etiquette of coughing and sneezing, and avoiding touching face area. However, there is a slightly lower level of knowledge in proper mask material and an attitude of frightened hearing the COVID-19 mortality rate. There are also significant roles in socioeconomic status with knowledge levels. Hence, it is necessary to pay more attention to socioeconomic status to increase the effectiveness of health promotion.

\section{References}

1. World Health Organization. Indonesia: WHO Coronavirus Disease (COVID-19) Dashboard with Vaccination Data. Geneva: World Health Organization; 2021. Available from: https://www.covid19. who.int/region/searo/country/id [Last accessed on 2021 Jun 20].

2. Djalante R, Lassa J, Setiamarga D, Sudjatma A, Indrawan M, Haryanto $\mathrm{B}$, et al. Review and analysis of current responses to COVID-19 in Indonesia: Period of January to March 2020. Prog Disaster Sci. 2020;6:1-8. https://doi.org/10.1016/j. pdisas.2020.100091

3. Haug N, Geyrhofer L, Londei A, Dervic E, Desvars-Larrive A, Loreto $\mathrm{V}$, et al. Ranking the effectiveness of worldwide COVID19 government interventions. Nat Hum Behav. 2020;4(12):130312. https://doi.org/10.1101/2020.07.06.20147199 PMid:33199859

4. United Nations Children's Fund. Children in Indonesia; 2021. Available from: https://www.unicef.org/indonesia/id/anak-anakdi-indonesia. [Last accessed on 2021 Jun 20].

5. Dewi R, Kaswandani N, Karyanti M, Setyanto D, Pudjiadi A Hendarto A, et al. Mortality in children with positive SARS-CoV-2 polymerase chain reaction test: Lessons learned from a tertiary referral hospital in Indonesia. Int J Infect Dis. 2021;107:78-85. https://doi.org/10.1016/j.ijid.2021.04.019

PMid:33857609

6. Busa F, Bardanzellu F, Pintus MC, Fanos V, Marcialis MA. COVID19 and school: To open or not to open, that is the question: To first review on current knowledge. Pediatric Rep. 2021;13:25778. https://doi.org/10.3390/pediatric13020035

7. Viner RM, Russell SJ, Croker H, Packer J, Ward J, Stansfield C, et al. School closure and management practices during coronavirus outbreaks including COVID-19: A rapid systematic review. Lancet Child Adolesc Health. 2020;4(5):397-404. https:// doi.org/10.1016/s2352-4642(20)30095-x

8. Loasana NA, Syakriah A. Government Pushes for School Reopening; 2021. Available from: https://www.thejakartapost. com/news/2021/04/04/government-pushes-for-schoolreopening.html [Last accessed on 2021 Jun 20].

9. Centers for Disease Control and Prevention: COVID-19 Vaccines for Children and Teens; 2021. Available from: https://www. cdc.gov/coronavirus/2019-ncov/vaccines/recommendations/ adolescents.html\#print [Last accessed on 2021 Jun 20].

10. John Hopkins Medicine: COVID-19 Vaccine: What Parents Need to Know; 2021. Available from: https://www.hopkinsmedicine.org/ health/conditions-and-diseases/coronavirus/covid19-vaccinewhat-parents-need-to-know [Last accessed on 2021 Jun 20]. https://doi.org/10.4324/9780203299494_chapter_1

11. Perkasa G. Face-to-face school cannot be reopened. Why? 2020. Available from: https://www.lifestyle.kompas.com read/2020/12/23/172820620/sekolah-tatap-muka-belum-bisadibuka-kembali-kenapa?page=all [Last accessed on 2021 Jun 20].

12. Ikatan Dokter Anak Indonesia. IDAI Response Regarding Schoo Reopening For Face-to-face Learning; 2021. Available from: https://www.idai.or.id/tentang-idai/pernyataan-idai/tanggapanidai-terkait-pembukaan-sekolah-untuk-pembelajarantatap-muka [Last accessed on 2021 Jun 20]. https://doi. org/10.1163/1574-9347_dnp_e606910

13. Saxena R. Preparing children for pandemics. In: Saxena S editor. Coronavirus Disease 2019 (COVID-19): Epidemiology, Pathogenesis, Diagnosis, and Therapeutics. Singapore: Springer; 2020. p. 187-98. https://doi.org/10.1007/978-981-15-4814-7_15

14. Muslih M, Susanti $H$, Rias $Y$, Chung M. Knowledge, attitude, and practice of Indonesian residents toward COVID-19: A cross-sectional survey. Int J Environ Res Public Health. 2021;18(9):4473. https://doi.org/10.3390/ijerph18094473 


\section{PMid:33922420}

15. Al-Ahdab S. A cross-sectional survey of knowledge, attitude and practice (KAP) towards COVID-19 pandemic among the Syrian residents. BMC Public Health. 2021;21(1):296. https:// doi.org/10.1186/s12889-021-10353-3

\section{PMid:33546652}

16. Lee $M$, Kang B, You M. Knowledge, attitudes, and practices (KAP) toward COVID-19: A cross-sectional study in South Korea. BMC Public Health. 2021;21(1):295. https://doi.org/10.1186/ s12889-021-10285-y PMid:33546644

17. Shahin MA, Hussien RM. Risk perception regarding the COVID-19 outbreak among the general population: A comparative Middle East survey. Middle East Curr Psychiatry. 2020;27(1):71.https://doi.org/10.1186/s43045-020-00080-7

18. Faul F, Erdfelder E, Buchner A, Lang AG. Statistical power analyses using $G^{*}$ Power 3.1: Tests for correlation and regression analyses. Behav Res Methods. 2009;41(4):1149-60. https://doi. org/10.3758/brm.41.4.1149

PMid:19897823

19. Nourmoradi H, Kazembeigi F, Kakaei H, Jalilian M, Mirzaei A. Assessment of knowledge, attitude, and practice toward COVID- 19 among a sample of Iranian general population. Open Access Maced J Med Sci. 2020;8:167-74. https://doi. org/10.3889/oamjms.2020.5094

20. DeCoster J, Gallucci M, Iselin AM. Best practices for using median splits, artificial categorization, and their continuous alternatives. J Exp Psychopathol. 2011;2(2):197-209. https:// doi.org/10.5127/jep.008310

21. Abuhammad S. Parents' knowledge and attitude towards COVID-19 in children: A Jordanian study. Int J Clin Pract. 2020;75(2):1-6. https://doi.org/10.1111/ijcp.13671

22. Roy D, Tripathy S, Kar S, Sharma N, Verma S, Kaushal V. Study of knowledge, attitude, anxiety and perceived mental healthcare need in Indian population during COVID-19 pandemic. Asian J Psychiatr. 2020;51:102083. https://doi.org/10.1016/j. ajp. 2020.102083

PMid:32283510

23. Zhong B, Luo W, Li H, Zhang Q, Liu X, Li W, et al. Knowledge, attitudes, and practices towards COVID-19 among Chinese residents during the rapid rise period of the COVID-19 outbreak: A quick online cross-sectional survey. Int J Biol Sci. 2020;16(10):1745-52. https://doi.org/10.7150/ijbs.45221 PMid:32226294

24. Hager E, Odetokun IA, Bolarinwa O, Zainab A, Okechukwu O, Al-Mustapha Al. Knowledge, attitude, and perceptions towards the 2019 Coronavirus pandemic: A bi-national survey in Africa. PLoS One. 2020;15(7):e0236918. https://doi.org/10.1371/ journal.pone.0236918 PMid:32726340

25. Islam S, Emran G, Rahman E, Banik R, Sikder T, Smith L, et al. Knowledge, attitudes and practices associated with the COVID- 19 among slum dwellers resided in Dhaka City: A Bangladeshi interview-based survey. J Public Health. 2020;43(1):13-25. https://doi.org/10.1093/pubmed/fdaa182 PMid:33057666

26. Lau LL, Hung N, Go DJ, Ferma J, Choi M, Dodd W, et al. Knowledge, attitudes and practices of COVID-19 among incomepoor households in the Philippines: A cross-sectional study.
J Glob Health. 2020;10(1):011007. https://doi.org/10.7189/ jogh.10.011007

PMid:32566169

27. Bono S, de Moura Villela EF, Siau C, Chen W, Pengpid S, Hasan $M$, et al. Factors affecting COVID-19 vaccine acceptance: An international survey among low-and MiddleIncome Countries. Vaccines (Basel). 2021;9(5):515. https://doi. org/10.3390/vaccines9050515 PMid:34067682

28. Kar S, Oyetunji T, Prakash A, Ogunmola O, Tripathy S, Lawal M, et al. Mental health research in the lower-middle-income countries of Africa and Asia during the COVID-19 pandemic: A scoping review. Neurol Psychiatry Brain Res. 2020;38:54-64. https://doi.org/10.1016/j.npbr.2020.10.003 PMid:33162686

29. Tee M, Wang C, Tee C, Pan R, Reyes P, Wan X, et al. Impact of the COVID-19 pandemic on physical and mental health in lower and upper middle-income Asian countries: A comparison between the Philippines and China. Front Psychiatry. 2021;11:568929. https://doi.org/10.3389/fpsyt.2020.568929 PMid:33633595

30. Alifia U. COVID-19 is Widening Indonesia's Education Gap; 2020. Available from: https://www.eastasiaforum. org/2020/10/22/covid-19-is-widening-indonesias-education-gap [Last accessed on 2021 Jun 20].

31. Erfani A, Shahriarirad R, Ranjbar K, Mirahmadizadeh A, Moghadami M. Knowledge, Attitude and Practice toward the Novel Coronavirus (COVID-19) Outbreak: A PopulationBased Survey in Iran; 2021. Available from: https://www. who.int/bulletin/online_first/20-256651.pdf [Last accessed on 2021 Jul 01]. https://doi.org/10.2471/blt.20.256651

32. Galasso V, Pons V, Profeta P, Becher M, Brouard S, Foucault M Gender differences in COVID-19 attitudes and behavior: Panel evidence from eight countries. Proc Natl Acad Sci USA. 2020;117(44):27285-91. https://doi.org/10.1073/pnas.2012520117 PMid:33060298

33. Lau LL, Hung N, Go DJ, Ferma J, Choi M, Dodd, W, et al Gender differences in COVID-19 sentiments, attitudes, habits, and behaviors: An empirical research. J Res Gend Stud. 2020;10(2):95. https://doi.org/10.22381/jrgs10220205

34. NandeA, Adlam B, Sheen J, Levy MZ, Hill AL. Dynamics of COVID19 under social distancing measures are driven by transmission network structure. PLoS Comput Biol. 2021;17(2):e1008684. https://doi.org/10.1371/journal.pcbi.1008684 PMid:33534808

35. United Nations Children Fund, United Nations Development Programme, Prospera, SMERU. Analysis of the Social and Economic Impacts of COVID-19 on Households and Strategic Policy Recommendations for Indonesia; 2021. Available from: https://www.smeru.or.id/en/content/analysissocial-and-economic-impacts-covid-19-households-andstrategic-policy [Last accessed on 2021 Jun 20]. https://doi. org/10.18356/9789210053709c011

36. Mitjà $\mathrm{O}$, Clotet $\mathrm{B}$. Use of antiviral drugs to reduce COVID-19 transmission. Lancet Glob Health. 2020;8(5):639-40. https://doi. org/10.1016/s2214-109x(20)30114-5 PMid:32199468

37. Julita SL. Indonesian Workers are Still Dominated by Elementary Graduates and Below, CNBC Indonesia; 2021. Available from: https://www.cnbcindonesia.com [Last accessed on 2021 Jun 27]. 


\section{Appendix}

\section{Appendix A: Questionnaire used in this study}

\begin{tabular}{|c|c|}
\hline \multicolumn{2}{|c|}{ Items no } \\
\hline \multicolumn{2}{|c|}{ Knowledge } \\
\hline \multicolumn{2}{|r|}{ 1. COVID-19 is a contagious disease caused by a virus } \\
\hline \multicolumn{2}{|r|}{ 2. COVID-19 cannot infect children } \\
\hline \multicolumn{2}{|r|}{ 3. Ikatan Dokter Anak Indonesia (IDAI) has allowed school to reopen } \\
\hline \multicolumn{2}{|r|}{$\begin{array}{l}\text { 4. According to the World Health Organization (WHO), children under } 5 \text { years old are } \\
\text { not recommended to use masks }\end{array}$} \\
\hline \multicolumn{2}{|r|}{ 5. Children who do not show any symptoms are unlikely to catch COVID-19 } \\
\hline \multicolumn{2}{|r|}{ 6. One of the symptoms of COVID-19 in children is fever } \\
\hline \multicolumn{2}{|r|}{ 7. COVID-19 infection is not life-threatening or harmless to children } \\
\hline \multicolumn{2}{|r|}{$\begin{array}{l}\text { 8. Person to person transmission of COVID-19 can occur through droplets (while } \\
\text { talking, sneezing, coughing, singing, etc.) }\end{array}$} \\
\hline \multicolumn{2}{|r|}{$\begin{array}{l}\text { 9. The use of a face shield (without a mask) alone is sufficient to protect children from } \\
\text { COVID-19 }\end{array}$} \\
\hline \multicolumn{2}{|r|}{$\begin{array}{l}\text { 10. Children over the age of } 5 \text { who are healthy (without symptoms) do not need to wear } \\
\text { a mask }\end{array}$} \\
\hline \multirow{2}{*}{\multicolumn{2}{|c|}{$\begin{array}{l}\text { 11. Children are encouraged to maintain personal hygiene (washing hands, showering } \\
\text { after traveling, etc.) to prevent COVID-19 } \\
\text { 12. Healthy children (without comorbidities) only need to use a three-layer cloth mask }\end{array}$}} \\
\hline & \\
\hline \multicolumn{2}{|r|}{ Attitude } \\
\hline \multicolumn{2}{|r|}{ 1. I understand how COVID-19 is transmitted } \\
\hline \multicolumn{2}{|r|}{ 2. I understand how to prevent COVID-19 } \\
\hline \multicolumn{2}{|r|}{ 3. Hearing the news of the death of COVID-19 scares me } \\
\hline \multicolumn{2}{|r|}{$\begin{array}{l}\text { 4. I am afraid that my child will be infected with COVID-19 when he/she goes back } \\
\text { to school }\end{array}$} \\
\hline \multicolumn{2}{|r|}{ 5. My child (ren) will be safer studying from home rather than at school } \\
\hline \multicolumn{2}{|r|}{ 6. I do not agree for schools to reopen } \\
\hline \multicolumn{2}{|r|}{ 7. I will teach my children on how to prevent COVID-19 } \\
\hline \multicolumn{2}{|r|}{ 8. My child (ren) are getting bored at home because of COVID-19 } \\
\hline \multicolumn{2}{|r|}{ Behavior } \\
\hline \multicolumn{2}{|r|}{ 1. I will prepare food and utensils from home } \\
\hline \multicolumn{2}{|r|}{ 2. I will prepare a mask for my child before going to school } \\
\hline \multicolumn{2}{|r|}{ 3. I will prepare a face shield for my child before going to school } \\
\hline \multicolumn{2}{|r|}{ 4. I will clean or disinfect my child's school supplies everyday } \\
\hline \multicolumn{2}{|r|}{ 5. I will teach my child (ren) to wash his/her hands properly } \\
\hline \multicolumn{2}{|r|}{$\begin{array}{l}\text { 6. I will teach my child how to maintain a distance of minimum } 1 \text { meter from his/her } \\
\text { friends }\end{array}$} \\
\hline & I will teach my child the proper etiquette of coughing and sneezing \\
\hline & I will teach my child not to touch the eye, nose, and mouth area while in school \\
\hline & I will not take my child out if it is not needed \\
\hline & $\begin{array}{l}\text { I will rest my child at home if there are signs and symptoms of COVID-19 (fever, } \\
\text { cough, runny nose, diarrhea, etc) }\end{array}$ \\
\hline
\end{tabular}

